\title{
ANALISIS KAJIAN STRUKTURAL DALAM NOVEL MARYAMAH KARPOV KARYA ANDREA HIRATA
}

\author{
Nova Andarini \\ Jurusan Pendidikan Bahasa dan Sastra Indonesia \\ PPs Universitas Negeri Medan \\ Novaandarini25@gmail.com
}

\begin{abstract}
Abstarak . Penelitian ini mendeskripsikan hasil analisis struktural novel "Maryamah Karpov" karya Andrea Hirata. Penelitian analisis struktural ini meliputi Judul, Tema, Tokoh dan Penokohan, Latar, Konflik. Penelitian pada novel Maryamah Karpov menggunakan metode kualitatif. Dalam tahap analisis data, Penulis akan mendeskripsikan analisis data. Langkah yang dilakukan yaitu menganalisis novel maryamah karpov karya Andrea Hirata berdasarkan struktural.
\end{abstract}

Kata Kunci: Kajian Struktural, Novel, Maryamah Karpov

\section{PENDAHULUAN}

Novel merupakan hasil karya sastra yang mempunyai peranan penting, artinya bahwa kedudukan novel sama dengan ilmu pengetahuan yang lain, yaitu sesuatu yang penting bagi kemajuan masyarakat. Novel tidak sekedar merupakan serangkaian tulisan yang menggairahkan ketika dibaca, tetapi merupakan struktur pikiran yang tersusun dari unsur-unsur yang padu. Untuk mengetahui makna atau pikiran tersebut, karya sastra (novel) harus dianalisis.

Novel Maryamah Karpov karya Andrea Hirata merupakan novel yang menarik. Secara umum, novel tersebut menceritakan tentang kehidupan sosial masyarakat yang ada di Pulau Belitung, mulai dari kelompok sosial masyarakatnya, kebudayaanya, proses sosial yang terjadi dalam masyarakatnya, serta fenomena-fenomena lain yang sangat unik. Secara khusus, novel ini mengisahkan tentang besarnya perjuangan cinta seseorang, yaitu Ikal terhadap kekasihnya yang bernama A Ling.

\section{METODE PENELITIAN}

Metode penelitian yang digunakan dalam penelitian ini adalah metode kualitatif dengan teknik studi pustaka dan analisis data. Dalam melakukan studi pustaka, peneliti menelaah datadata yang berupa buku-buku. Adapun data primer dari penelitian ini adalah novel Maryamah Karpov karya Andrea Hirata. Sedangkan datadata sekundernya adalah buku-buku sastra yang terkait dengan objek penelitian. Data- 
data yang telah dipilih kemudian dianalisis secara deskriptif, yaitu dengan cara menguraikan dengan menggunakan teori sosiologi.

Dalam konteks penelitian sastra, metode kualitatif diimplementasikan dalam pendekatan struktural dan pragmatik. Pendekatan struktural diimplementasikan dalam analisis struktural, Pendekatan struktural merupakan suatu pendekatan kesastraan yang menekankan pada kajian hubungan antar unsur pembangun karya yang bersangkutan (Nurgiyantoro, 2005:36-37).

\section{ANALISIS STRUKTURAL}

\section{Analisis Struktural}

\subsection{Judul}

Judul novel Maryamah Karpov karya Andrea Hirata menunjukkan tokoh (bawahan) yang terdapat dalam novel tersebut. Maryamah Karpov diambil dari nama salah satu tokoh bawahan yang ada dalam novel ini, yaitu Mak Cik Maryamah, yang kemudian lebih akrab dengan sebutan Maryamah Karpov karena sering mengajari orang tentang langkahlangkah bermain catur ala Antoly Yevgenyevich Karpov, seorang Grandmaster catur dari Rusia.

\subsection{TEMA}

Tema merupakan gagasan umum yang mendasari penulisan sebuah cerita. Tema dibagi menjadi dua, yaitu tema mayor dan tema minor.

\section{Tema Mayor}

Tema mayor yang terdapat dalam novel Maryamah Karpov karya Andrea Hirata adalah perjuangan keras seseorang demi mencari cinta sejatinya. Data yang mendukung sebagai berikut.
... Dadaku sesak. Aku akan mendatangi semua tempat itu. Kan kucari A Ling dan kan kutemukan dia, apa pun yang harus kuhadapi, apa pun yang akan terjadi, karena aku telah mencarinya separuh dunia. Aku ingin menemukannya, walau keadaannya akan menghancurkan hatiku $(M K: 222)$.

Tokoh Ikal bertekad akan mendatangi semua tempat di muka bumi ini untuk mencari dan menemukan A Ling, kekasihnya. Ikal tidak pernah menyerah. Keinginan Ikal untuk bertemu A Ling sangat besar. Apa pun yang terjadi, akan ia hadapi demi menemukan kekasihnya tersebut.

\section{Tema Minor}

Tema minor merupakan tema tambahan yang terdapat dalam cerita. Beberapa tema minor dalam novel Maryamah Karpov karya Andrea Hirata di antaranya sebagai berikut.

1) Kasih sayang dan perjuangan orang tua untuk membahagiakan anaknya

$$
\text { Ayah berdiri siaga, ingin }
$$
memboncengku. Kuingatkan bahwa aku sudah tak kecil lagi, aku sudah besar dan berat. Wajahnya tegak, menatap lurus. Itu artinya: Bujang, janganlah banyak komentarmu, aku sudah tahu, naik saja. (MK:112).

Kasih sayang seorang ayah kepada anaknya dapat diwujudkan melalui hal-hal yang sangat sederhana, seperti yang dilakukan oleh ayah Ikal. Ayah Ikal yang bersikeras ingin membonceng Ikal, meskipun ia tahu bahwa Ikal sudah besar dan tentunya berat.

2) Persahabatan tidak lekang oleh waktu

... Mereka adalah pahlawanpahlawanku, para pemangku sumpah setia 
persahabatan, para Laskar Pelangi: A Kiong, Syahdan, Sahara, Kucai, Flo, Trapani, dan Harun.Aku menghampiri mereka. Kami bersalaman erat dan berpelukan. Para Laskar Pelangi, sahabatsahabat sejati yang tak lekang oleh waktu.... (MK:253).

Begitu besar solidaritas persahabatan yang dimiliki oleh sahabat-sahabat Ikal yang tergabung dalam anggota Laskar Pelangi. Meski telah lama berpisah, mereka masih tetap menjaga ikatan persahabatan yang telah mereka bina sejak di sekolah dasar.

\subsection{TOKOH DAN PENOKOHAN}

\section{Tokoh Utama}

Tokoh utama dalam novel Maryamah Karpov karya Andrea Hirata adalah Ikal. Ikal merupakan tokoh yang paling dominan diceritakan dalam novel tersebut. Ikal juga tokoh yang paling dominan mengalami konflik.

"Kau ini, Kal! Hanya karena cinta, kau mau ke Batuan?”

Aku diam, tetap menuntut jawaban. "Dari dulu kau selalu keras kepala!"

La'ani berusaha mengurungkan niatku. Tapi aku menunjukkan sikap membatu.

"Kau rela mati untuk cinta? Pahamkah kau? Betapa sintingnya kau itu?" (MK:225).

Ikal merupakan tipikal orang yang keras kepala. Setiap kali Ikal memiliki kemauan, sangat sulit untuk menangguhkan kemauannya tersebut. Apalagi jika sudah berkaitan dengan masalah cinta, Ikal pasti berani melakukan apa pun demi cinta, bahkan dengan mempertaruhkan nyawanya sendiri. Meskipun keras kepala, namun Ikal juga merupakan sosok yang baik dan penyayang.

\section{Tokoh Bawahan}

Tokoh bawahan atau tokoh tambahan adalah tokoh yang kehadirannya berhubungan dengan tokoh utama baik secara langsung ataupun secara tidak langsung. Beberapa tokoh bawahan yang ada dalam novel Maryamah Karpov karya Andrea Hirata adalah Ayah, Lintang, A Ling, Eksyen, dan Ketua Karmun.

1) Ayah

Tokoh Ayah, dalam novel Maryamah Karpov karya Andrea Hirata digambarkan sebagai sosok yang pendiam dan tidak banyak bicara.

Ayah masih saja pendiam. Sering aku bertanya pada diri sendiri: mengapa ayahku begitu pendiam?

Aku ingat, selama kelas satu SMA dulu aku hanya mendapat tujuh kaliamat darinya. Kelas dua turun jadi lima, dan selama kelas tiga ada peningkatan sedikit: delapan kalimat (MK:90).

Tokoh Ayah merupakan sosok yang sangat pendiam dan hampir tidak pernah bicara. Ikal tidak tahu, mengapa ayahnya bersikap demikian. Ikal berpikir bahwa sesuatu yang buruk pernah menimpa ayahnya, sehingga ayahnya menjadi sangat pendiam. Selama SMA, Ikal hanya mendapat dua puluh kalimat dari ayahnya.

2) Lintang

Tokoh Lintang dalam novel Maryamah Karpov karya Andrea Hirata digambarkan sebagai tokoh yang sangat cerdas. Lintang adalah sahabat Ikal sejak duduk di bangku 
sekolah dasar. Setelah dewasa, Lintang menjadi juragan kopra yang sangat sukses.Membuat sesuatu yang rumit menjadi begitu sederhana adalah keahlian khusus Lintang yang selalu membuatku iri.

Lelaki pandai yang rendah hati itu tersenyum kecil saja melihatku terperangah. Ia mohon diri sembari memberikan petuah terakhirnya (MK:285-286).

Lintang merupakan tokoh yang sangat cerdas dan jenius. Kecerdasan dan kejeniusan Lintang telah tampak sejak ia duduk di bangku sekolah dasar. Segala sesuatu yang rumit dapat diubahnya menjadi lebih mudah. Lintang selalu menempatkan ilmu sebagai dasar pemikirannya. Meskipun sangat cerdas dan jenius, Lintang tetap bersikap rendah hati. Ia tidak menyombongkan diri atas kepandaian dan kecerdasan yang ia miliki.

\section{3) A Ling}

A Ling adalah kekasih Ikal. Ia gadis dari suku Ho Pho yang merupakan keturunan prajurit Ho Pho, yaitu tentara bayaran dari dataran Tiongkok, kongsi kompeni zaman dahulu.

Perempuan Ho Pho itu tersenyum padaku. Napasku macet. Dulu waktu remaja ia seperti Michelle Yeoh, kini dewasa, ia dua kali lebih cantik. Tinggi semampai, mengenakan pakaian favoritnya, chong kiun biru muda yang rapat sampai mata kaki ... Rambutnya yang telah dipotong tak terlalu panjang lagi tapi juga tak terlalu pendek ... Paras-paras kuku, yang ia tumpangkan di atas lutut, seindah mutiara raja brana, menyambar seluruh perhatianku $(M K: 452)$.
Secara fisik, A Ling digambarkan sebagai tokoh yang sangat cantik, tinggi semampai, rambutnya tidak terlalu panjang dan tidak terlalu pendek. A Ling sering mengenakan pakaian Chong Kiun berwarna biru muda yang rapat sampai mata kaki. Ia terlihat sangat anggun dan lembut. Hal itu membuat Ikal sangat mencintai A Ling, hingga ia rela melakukan apa pun demi A Ling.

\section{4) Eksyen}

Eksyen, dalam novel Maryamah Karpov karya Andrea Hirata digambarkan sebagai tokoh yang sering menghina orang. Nama asli Eksyen adalah Masridin bin Yakoeb Oemar. Ia dipanggil Eksyen karena cita-citanya menjadi artis (bintang film) tidak tercapai, sehingga orang- orang memberinya julukan action (eksyen).

Eksyen adalah orang yang dalam dirinya dijejali hasrat untuk menghina. Wajahnya selalu seperti orang ingin menyindir. Tak terbilang banyaknya gadis Melayu yang enggan keluar rumah karena tak tahan akan julukanjulukan merendahkan yang dilekat-lekatkan Eksyen pada meraka... (MK:239).

Eksyen merupakan sosok manusia yang selalu berhasrat untuk menghina orang lain. Ia sangat gemar menjuluki orang dengan namanama ejekan yang sangat merendahkan. Banyak gadis-gadis Melayu yang ia juluki dengan julukan yang buruk, sehingga mereka enggan untuk keluar rumah, karena takut mendapat julukan yang buruk dari Eksyen.

5) Ketua Karmun

Ketua Karmun, dalam novel Maryamah Karpov karya Andrea Hirata digambarkan sebagai tokoh yang menjengkelkan namun humoris, tulus, dan dicintai banyak orang. Nama 
asli Ketua Karmun adalah Karmun Azizi bin Saidi Syahran. Ia dipanggil Ketua Karmun karena jabatannya sebagai kepala kampung.

sudah banyak kukenal orang. Baru kutemukan yang model Ketua Karmun: saklek, humoris, tanpa tedeng aling-aling. Hemat kata, Ketua Karmun adalah pria yang dramatis. Tapi rakyatnya cinta setengah mati padanya. Karena di balik sikap yang menjengkelkan itu, tulusnya tiada banding $(M K: 87)$.

Ketua Karmun merupakan seorang kepala kampung yang saklek, humoris, dan tanpa tedeng aling-aling. Meski agak menjengkelkan, Ketua Karmun sangat dicintai oleh rakyatnya karena ketulusan yang dimilikinya. Sebagai kepala kampung, Ketua Karmun benar-benar mengemban tugasnya dengan penuh tanggung jawab.

\section{6) Maryamah Karpov}

Maryamah Karpov merupakan tokoh bawahan dalam novel Maryamah Karpov karya Andrea Hirata. Nama asli Maryamah Karpov adalah Mak Cik Maryamah. Ia lebih akrab dipanggil dengan sebutan Maryamah Karpov karena sering mengajari orang tentang langkahlangkah bermain catur ala Antoly Yevgenyevich Karpov. Tokoh Mak Cik Maryamah hampir tidak pernah disinggung dalam novel ini. Ia hanya disebutkan sebagai pemain catur yang sesekali muncul di warung kopi. Hal ini dapat dilihat pada data berikut.

... Di sinilah markas besar mereka, di warung kopi terbesar di kampung kami. Tak kira-kira, rata- rata tujuh ratus lima puluh gelas kopi setiap pagi, dan berpuluh-puluh papan catur digelar dari sore hinggasore lagi. Di warung kopi ini nongkrong ratusan lelaki Melayu pemalas yang menyingsingkan lengan baju untuk makan dan berkeringat karena kenyang. Di antara mereka, terkadang tampak pula Mak Cik Maryamah yang seringkali mengajari orang langkahlangkah catur Karpov (MK:240).

Data tersebut menunjukkan aktivitas yang terjadi di sebuah warung kopi yang bernama Usah Kau Kenang Lagi. Setiap hari, di warung kopi tersebut selalu berkumpul ratusan lelaki Melayu pemalas untuk sekadar bersenang-senang, makan, minum kopi, dan bermain catur. Di antara ratusan lelaki Melayu tersebut sering muncul Mak Cik Maryamah. Ia mengajari orang-orang yang ada di warung tersebut tentang langkah-langkah permainan catur Antoly Yevgenyevich Karpov, seorang Grandmaster catur yang berasal dari Rusia. Penokohan pada Mak Cik Maryamah (Maryamah Karpov) tidak dapat diketahui dengan detail karena kemunculannya dalam novel ini sangat terbatas.

\subsection{LATAR}

\section{Latar Tempat}

Latar tempat menyaran pada lokasi terjadinya peristiwa yang diceritakan dalam karya sastra. Beberapa latar tempat yang sering disebutkan dalam novel Maryamah Karpov karya Andrea Hirata di antaranya sebagai berikut.

1) Warung Kopi Usah Kau Kenang Lagi

Warung Kopi Usah Kau Kenang Lagi merupakan warung kopi terbesar yang ada di Pulau Belitung.

Para Kesatria Timur selalu berkumpul di Warung Kopi Usah Kau Kenang Lagi ini. Di sinilah markas besar mereka, di warung kopi terbesar di kampung kami.... (MK:240). 
Warung kopi Usah Kau Kenang Lagi dijadikan sebagai tempat berkumpulnya para pemain catur kelas satu di Pulau Belitung. Mereka terkenal dengan sebutan Kesatria Timur.

\section{2) Sungai Linggang}

Sungai Linggang adalah sebuah sungai yang terletak di desa Linggang, kecamatan Gantung, Kabupaten Belitung Timur. Karena letaknya berada di desa Linggang, akhirnya sungai ini diberi nama Sungai Linggang.Lalu kami berperang dengan buah berang. Menangkas pucuk-pucuk mudanya, berteriak-teriak tarzan, sesumbar diri anak Melayu paling perkasa, dan melompat dari lengan dahannya ke permukaan Sungai Linggang (MK:80-81).

Saat masih kecil, Ikal dan kawankawannya sering bermain perang-perangan di sekitar Sungai Linggang. Mereka berperang dengan menggunakan buah phon berang yang tumbuh di sekitar sungai tersebut, melompat dari lengan dahannya ke permukaan sungai Linggang, dan berteriak- teriak seperti Tarzan 3) SD Muhammadiyah (Sekolah Laskar Pelangi)

SD Muhammadiyah adalah sekolah tempat Ikal dan sahabat-sahabatnya menuntut ilmu. Sekolah tersebut dikenal sebagai sekolah Laskar Pelangi karena siswa-siswi yang sekolah di sana sangat menyukai pemandangan pelangi yang biasa muncul di dekat sekolah tersebut.

Sungguh menyedihkan keadaan sekolah kami sekarang. Dulu ia dikucilkan zaman, sekarang ia masih senyap sendirian. Kami tertegun bergandengan tangan $(M K: 257)$. Saat Ikal dan kawan-kawannya masih duduk di bangku sekolah dasar, Sekolah Laskar Pelangi tidak pernah mendapatkan perhatian dari masyarakat sekitar maupun dari aparat pemerintah. Hanya ada sepuluh murid dengan seorang guru di sekolah tersebut. Sepuluh murid itulah yang kemudian dikenal dengan sebutan Laskar Pelangi, yaitu Ikal dan kawankawannya. Saat Ikal dan kawan-kawannya telah dewasa, sekolah Laskar Pelangi semakin sunyi, karena tidak ada satu pun siswa yang menuntut ilmu di sekolah tersebut.

4) Pulau Batuan

Pulau Batuan, dalam novel Maryamah Karpov karya Andrea Hirata digambarkan sebagai suatu pulau yang sangat menyeramkan, karena dikuasai oleh seorang bajak laut bernama Tuk Bayan Tula. Siapapun yang berkunjung ke pulau tersebut, tidak akan dapat pulang dengan selamat.

... Kenyataan ini meyakinkanku bahwa ekspedisi ke Batuan tak kan sekedar perjalanan berbahaya menghadapi badai dan bajak laut Selat Malaka demi mencari A Ling, tapi di negeri laut dan kepulauan ini, akan pula aku bertemu halhal baru yang misterius dan mencengangkan (MK:373).

Demi menemukan kekasihnya, Ikal nekat berlayar ke Pulau Batuan. Perjalanan Ikal ke Pulau Batuan untuk mencari A Ling merupakan petualangan yang sangat menantang. Ikal harus menghadapi badai dan bajak laut yang menguasai Selat Malaka untuk dapat sampai di Pulau Batuan. Selain badai dan bajak laut, Ikal juga dipertemukan dengan hal-hal yang misterius dan mencengangkan.

\section{Latar Waktu}

Latar waktu berhubungan dengan masalah 'kapan' terjadinya peristiwa-peristiwa yang diceritakan dalam sebuah karya sastra. Beberapa latar waktu dalam novel Maryamah Karpov 
karya Andrea Hirata di antaranya sebagai berikut.

\section{1) Pagi hari}

Karena itu, saban pagi, kunikmati saja saatsaat ketika ibuku menjelma menjadi warta berita RRI pukul tujuh. Merepetlah sindiran tentang mengapa aku tak kunjung bekerja, tentang betapa pemalasnya anak-anak muda Melayu zaman sekarang ( $M K: 128)$.

Data tersebut menunjukkan kebiasaan yang dilakukan oleh tokoh Ibu setiap pagi. Ibu selalu menyindir Ikal, karena ia tidak segera bekerja. Ibu menganggap Ikal sebagai anak muda yang pemalas. Meskipun sadar sedang disindir, Ikal tetap saja menikmati saat-saat pagi bersama ibunya tersebut.

2) Sore hari

saban sore, usai asar, setelah melatih ekspresi kesetiaan empat puluh tahunnya, Arai bertandang ke rumah Zakiah (MK:195).

Data tersebut menunjukkan aktivitas yang biasa dilakukan oleh Arai, sepupu Ikal. Setiap sore, Arai selalu berlatih untuk menjadi pria yang setia, demi wanita pujaannya yang bernama Zakiah. Setelah itu, ia selalu pergi mengunjungi gadis tersebut di rumahnya.

\section{3) Malam hari}

Film usai, malam larut. Kami pulang melewati sabana terbuka. Purnama penuh, bola api merah jingga, bulat besar menyala seakan kami melintas tepi dunia $(M K: 125)$.

Data tersebut menunjukkan peristiwa pada saat Ikal dan ayahnya pulang menonton film. Saat itu, malam telah larut. Di bawah sinar purnama, Ikal dan ayahnya pulang melewati area sabana yang terbuka.
Latar sosial menyaran pada hal-hal yang berhubungan dengan perilaku kehidupan sosial masyarakat di suatu tempat yang diceritakan dalam karya sastra. Beberapa latar sosial yang terdapat dalam novel Maryamah Karpov karya Andrea Hirata yaitu sebagai berikut.

\section{"Boi!"}

Aih, rindunya aku dengan panggilan khas untuk anak muda Melayu di kampung kami itu.... (MK:60).

Data tersebut menunjukkan panggilan khas untuk anak muda yang digunakan oleh orang-orang Melayu di daerah pedalaman Belitung Timur, yaitu "boi".

Selain panggilan khas untuk anak-anak muda, dalam novel ini juga disebutkan ciri khas penamaan seseorang dalam konteks masyarakat Melayu Belitung. Hal ini dapat dilihat dari nama-nama tokoh yang terdapat dalam novel Maryamah Karpov karya Andrea Hirata, misalnya nama tokoh Lintang.

... Lintang Samudera Basara, sahabatku sebangku, lahir di pesisir, besar di pantai, putra tertua Syahbani Maulana Basara, tak lain seorang nelayan tangguh $(M K: 252)$.

Data tersebut menunjukkan nama tokoh Lintang, yaitu Lintang Samudera Basara. Di belakang nama Lintang terdapat nama ayahnya, yaitu Basara. Hal ini menunjukkan ciri khas orangorang Melayu Belitung yang selalu melekatkan nama orang tua (nama ayah) di belakang nama anak mereka.

\subsection{KONFLIK}

\section{Konflik Fisik}


Konflik fisik dapat terjadi antara manusia dan manusia; antara manusia dan masyarakat; serta antara manusia dan alam sekitarnya.

1) Konflik antara manusia dan manusia

Aku membuka kunci sepeda, masih sempat- sempatnya Eksyen mencelaku bahwa aku tak kan mampu menyelesaikan perahuku.

"Perahumu itu," cibirnya.

"Akan bernasib seperti hidupmu itu sendiri, Boi, setengah-setengah, selalu setengah-setengah."Rasanya aku ingin meninju hidungnya $(M K: 324)$.

Eksyen menghina dan mencibir Ikal yang tengah membuat perahu yang akan digunakan untuk berlayar ke Pulau Batuan guna mencari A Ling. Eksyen menyatakan bahwa Ikal tidak akan mampu menyelesaikan penggarapan perahunya. Perahu itu akan bernasib sama seperti hidup Ikal, hanya setengah- setengah. Sesungguhnya Ikal ingin marah saat mendengar pernyataan Eksyen tersebut, namun Ikal masih dapat mengendalikan emosinya.

2) Konflik antara manusia dan masyarakat

"Kudengar kau akan membuat perahu demi cinta, Kal, mau berlayar ke Batuan!?” cemooh Sema'un Barbara. Kumpulan cecunguk di warung kopi tertawa. Aku jadi bulan-bulanan (MK:237).

Ikal menjadi bulan-bulanan orang-orang Melayu yang sedang mangkal di warung kopi yang berada di belakang pasar ikan. Orangorang tersebut mencemooh Ikal lantaran rencananya membuat perahu untuk berlayar ke Pulau Batuan demi mencari A Ling, kekasihnya. Selain mencemooh, orang-orang Melayu tersebut juga menertawakan Ikal.
3) Konflik antara manusia dan alam sekitarnya

Aku mengayuh sepeda ayahku seperti orang kesurupan. Aku tak peduli meski hujan lebat dan tak sempat lagi memikirkan pelindung. Basah kuyup, dingin, dan angin kencang tak terasa menghalangiku. Aku berharap orang yang selamat itu masih tetap hidup sampai di rumah sakit $(M K: 213)$.

Data tersebut menunjukkan konflik yang terjadi terhadap diri Ikal yang berusaha melawan hujan lebat saat ia mengayuh sepedanya menuju rumah sakit. Angin kencang, udara yang sangat dingin, dan tubuhnya yang basah kuyup, benar-benar tidak menghalangi niatnya untuk segera sampai ke tempat tujuan.

\section{Konflik Batin}

1) Konflik antara ide dan ide lain

Minta ampun. Mahar melantur tak keruan. Kepalaku pening dibuat sayapsayap katanya yang melangit itu. Tadi perpustakaan di Pangkal Pinang, sekarang makhluk purba penguasa dasar sungai, sakit saraf tak terkira-kira! Tapi begitulah Mahar yang eksentrik, meracau, mengigau, dan bicara benar, sudah tak bisa dibedakan $(M K: 310-311)$.

Data tersebut menunjukkan adanya konflik antara ide yang satu dan ide lain yang terjadi pada tokoh Ikal. Ketika Mahar, sahabatnya, mengucapkan kata-kata yang sulit dipahami, Ikal menganggap bahwa Mahar sedang melantur. Namun di sisi lain, Ikal percaya bahwa perkataan Mahar yang sulit dipahami tersebut kadangkala benar. Sehingga, terjadilah konflik dalam pikiran (ide) ikal. 
2) Konflik antara seseorang dengan kata hatinya

"Ikal! Kuanggap kau adalah orang yang berpendidikan! Mana tanggung jawab ilmiahmu!"

Aku menunduk. Seisi kampung mahfum, kalau Ketua Karmun bicara jangan coba-coba dipotong. Aku hanya berani menjawab dalam hati, Apa hubungannya dengan ilmiah-ilmiah? Huh! Karbol, perban, darah, obat bius, jarum suntik, tak sudi aku! (MK:203-204).

Data tersebut menunjukkan konflik yang terjadi pada Ikal dengan kata hatinya saat Ketua Karmun memaksanya untuk berobat ke dokter gigi. Ikal tidak mau berobat ke dokter gigi lantaran trauma gara-gara pengalamannya saat disunat waktu ia masih kecil. Ikal tidak mau lagi berurusan dengan hal-hal yang menyangkut masalah kedokteran, seperti darah, jarum suntik, perban, karbol, dan obat bius. Ketua Karmun yang saat itu agak emosi, membuat Ikal tidak berani membantah, sehingga Ikal hanya berani menjawab dalam hati.

\section{SIMPULAN}

Analisis terhadap novel Maryamah Karpov karya Andrea Hirata menggunakan pendekatan struktural.

Judul novel Maryamah Karpov karya Andrea Hirata menunjukkan tokoh (bawahan) yang terdapat dalam novel tersebut. Maryamah Karpov merupakan nama dari salah satu tokoh bawahan yang ada dalam novel ini, yaitu Mak Cik Maryamah. Ia akrab disapa Maryamah Karpov karena sering mengajari orang tentang cara bermain catur ala Antoly Yevgenyevich Karpov, seorang Grandmaster catur dari Rusia.
Tema mayor yang terdapat dalam novel Maryamah Karpov adalah perjuangan keras seseorang demi menemukan cinta sejatinya, sedangkan beberapa tema minor dalam novel ini di antaranya ialah kasih sayang dan perjuangan orang tua untuk membahagiakan anaknya, serta persahabatan yang tidak lekang oleh waktu.

Tokoh utama dalam novel ini adalah Ikal. Ikal merupakan tokoh yang berwatak datar (flat character), yaitu yaitu keras kepala, namun pekerja keras, tidak mudah menyerah, pemberani, dan tekun. Sementara itu, tokohtokoh bawahan yang ada dalam novel ini di antaranya yaitu Ayah, Lintang, A Ling, Eksyen, dan Ketua Karmun. Kelima tokoh bawahan tersebut juga berwatak datar karena tidak mengalami perubahan watak secara signifikan.

Penggambaran latar dalam novel ini meliputi latar tempat, latar waktu, dan latar sosial. Latar tempat terjadi di Warung Kopi Usah Kau Kenang Lagi, Sungai Linggang, SD Muhammadiyah (Sekolah Laskar Pelangi), dan Pulau Batuan. Latar waktu terjadi pada pagi, sore, dan malam hari. Sedangkan latar dalam novel ini menunjukkan latar sosial masyarakat Melayu di pedalaman Pulau Belitung.

Konflik yang terdapat dalam novel Maryamah Karpov karya Andrea Hirata terdiri atas konflik fisik dan konflik batin. Konflik fisik antara manusia dan manusia terjadi antara Ikal dan Eksyen; konflik antara manusia dan masyarakat terjadi antara Ikal dan orang-orang yang berada di Warung Kopi Usah Kau Kenang Lagi; dan konflik antara manusia dan alam terjadi ketika Ikal berusaha melawan hujan lebat saat ia mengayuh sepedanya menuju rumah 
sakit. Sementara itu, konflik batin antara ide yang satu dan ide yang lain terjadi pada Ikal; konflik antara seseorang dengan kata hatinya terjadi pada tokoh Ikal dan kata hatinya.

Manfaat yang diperoleh setelah melakukan analisis struktural novel Maryamah Karpov karya Andrea Hirata yaitu bahwa manusia merupakan makhluk sosial, oleh sebab itu, manusia tidak dapat hidup sendiri. Setiap manusia pasti membutuhkan orang lain untuk mempertahankan dan memenuhi kebutuhan hidupnya. Dalam memenuhi suatu keinginan, setiap orang pasti membutuhkan usaha, kerja keras, dan kerja sama. Dengan bekerjasama, suatu tujuan atau cita-cita akan mudah untuk dicapai. Suatu perubahan ke arah yang lebih baik dapat terjadi apabila ada niat dan kemauan dalam diri setiap individu untuk melakukan perubahan.
Suatu masalah dapat diselesaikan dengan baik apabila semua pihak mau bekerja sama dalam menciptakan solusi dari masalah yang ada.

\section{SARAN}

Sehubungan dengan simpulan diatas maka analisis kajian struktural dapat diliat dari aspek Judul, Tema, Tokoh dan Penokohan, Latar, dan konflik. Manfaat yang diperoleh setelah melakukan analisis struktural novel Maryamah Karpov karya Andrea Hirata yaitu bahwa manusia merupakan makhluk sosial, oleh sebab itu, manusia tidak dapat hidup sendiri. Setiap manusia pasti membutuhkan orang lain untuk mempertahankan dan memenuhi kebutuhan hidupnya. Dalam memenuhi suatu keinginan, setiap orang pasti membutuhkan usaha, kerja keras, dan kerja sama. 


\section{DAFTAR PUSTAKA}

Faruk. 2012. Metode Penelitian Sastra: $\quad$ Sebuah Penjelajahan Awal. Yogyakarta: Pustaka Pelajar.

Hirata, A. 2008. Maryamah Karpov. Yogyakarta: Bentang Pustaka.

Hirata, A. 2011. Padang Bulan. Yogyakarta: Bentang Pustaka.

Maslikatin, T. 2007. Kajian Sastra: Prosa, Puisi, Drama. Jember: Jember University Press.

Nurgiyantoro, B. 2005. Teori Pengkajian Fiksi. Yogyakarta: Gajah Mada University Press.

Semi, A. 1990. Metode Penelitian Sastra. Bandung: Angkasa.

Tarigan, H. G. 2011. Prinsip-prinsip Dasar Sastra. Bandung: Angkasa.

Teeuw, A. 1984. Sastra dan Ilmu Sastra: Pengantar Teori Sastra. Jakarta: Pustaka Jaya 